Lingua Rima: Jurnal Pendidikan Bahasa dan Sastra Indonesia

Vol. 10 No. 1 Januari 2021

http://jurnal.umt.ac.id/index.php/lgrm

\title{
PENGGUNAAN LEMBAR KERJA MAHASISWA \\ DALAM PEMBELAJARAN DARING MATA KULIAH SEJARAH SASTRA \\ DI JBSI UNESA PADA MASA PANDEMI COVID-19
}

\author{
Hespi Septiana \\ Universitas Negeri Surabaya \\ hespiseptiana@unesa.ac.id \\ Suyatno, \\ Universitas Negeri Surabaya \\ Suyatno-b@unesa.ac.id \\ Fafi Inayatillah, \\ Universitas Negeri Surabaya \\ fafiinayatillah@unesa.ac.id \\ Yermia Nugroho Agung \\ Universitas Negeri Surabaya \\ yerminanugroho@unesa.ac.id
}

\begin{abstract}
ABSTRAK
Penelitian ini merupakan langkah dalam mengevaluasi pembelajaran daring yang sudah dilaksanakan sejak diumumkannya pandemi covid-19 sejak tanggal 12 Maret 2020 oleh WHO. Pelaksanaan perkuliahan daring masih menimbulkan berbagai permasalahan bagi dosen maupun mahasiswa. Pada penelitian ini, mata kuliah yang diteliti adalah mata kuliah Sejarah Sastra yang merupakan mata kuliah wajib untuk mahasiswa Program Studi Sastra Indonesia JBSI Unesa pada semester pertama. Melalui matakuliah Sejarah Sastra mahasiwa akan dikenalkan dengan perkembangan sastra Indonesia dari zaman sastra klasil sampai sastra modern, mengenalkan tokoh-tokoh sastrawan dan karyakaryanya. Mahasiswa yang memprogram mata kuliah ini merupakan mahasiswa baru yang belum pernah mendapatkan kuliah tatap muka. Tujuan penelitian ini (1) mengetahui problematika perkuliahan daring pada pembelajaran mata kuliah Sejarah Sastra (2) mengetahui solusi permasalahan pembelajaran daring mata kuliah Sejarah Sastra. Metode penelitian menggunakan metode kualitatif deskriptif. Tahapan penelitian dimulai dari perancangan penelitian melalui diskusi, penyusunan proposal, pengumpulan data, dan penyusunan laporan penelitian. Data diambil dari angket yang diisi oleh mahasiswa dan doskumentasi screenshoot dari pembelajaran daring.
\end{abstract}

Kata kunci: pembelajaran daring, covid-19, Sejarah Sastra

\section{A. PENDAHULUAN}

Sejak tanggal 12 Maret 2020, WHO menetapkan Covid-19 sebagai pandemi global. Kemudian pemerintah menerapkan kewajiban untuk melakukan jaga jarak bagi seluruh masyarakat Indonesia. Menanggapi aturan tersebut, sejak tanggal 16 Maret 2020 Universitas Negeri Surabaya melalui SE Rektor menyampaikan bahwa kegiatan akademik termasuk perkuliahan dilaksanakan dalam bentuk daring. Perkembangan covid-19 yang semakin 


\section{Lingua Rima: Jurnal Pendidikan Bahasa dan Sastra Indonesia \\ Vol. 10 No. 1 Januari 2021 \\ http://jurnal.umt.ac.id/index.php//grm}

meluas dan banyak, terlebih di Jawa Timur maka perkuliahan semester gasal tahun ajaran 2020/2021 kemungkinan besar juga dilaksanakan dalam bentuk daring.

Mahasiswa baru pada tahun ajaran tersebut harus beradaptasi menggunakan pembelajaran daring meskipun mereka belum pernah punya pengalaman kuliah. Hal ini menjadi tantangan tersendiri yang harus dihadapi oleh dosen dan mahasiswa. Salah satu mata kuliah yang diprogram oleh mahasiswa baru adalah mata kuliah Sejarah sastra. Mata kuliah Sejarah Sastra adalah mata kuliah wajib yang dipelajari mahasiswa Program Studi Sastra Indonesia. Sesuai dengan kurikulum Program Studi Sastra Indonesia mata kuliah Sejarah Sastra bisa diprogram oleh mahasiswa dengan beban 2 sks. Banyak mahasiwa yang masih merasa asing dengan sejarah sastra. Hal ini dinyatakan oleh penyataan seorang pengajar mata kuliah Sejarah Sastra bahwa saat mengajar pada pertemuan pertama masih banyak mahasiswa yang tidak mengetahui perihal Sejarah Sastra. Ditambah adanya beberapa kendala yang ditemui saat proses belajar mengajar seperti tidak adanya sinyal. Apabila pembelajaran hanya dilakukan dengan mengandalkan proses sinkronus tidak akan efektif sehingga dibutuhkan kegiatan belajar mengajar secara asinkronus.

Pembelajaran asinkronus tetap harus dilakukan dengan cara yang menarik dan efektif agar mahasiswa tidak merasa bosan. Mata kuliah sejarah sastra sering membuat mahasiswa bosan karena banyak komponen yang harus diketahui. Apabila dosen tidak mampu memberikan alternatif bahan ajar yang baik, hal itu akan menghambat pertumbuhan pengetahuan mahasiswa. Capaian pembelajaran mata kuliah ini ialah mahasiswa mempunyai kemampuan memahami konsep dasar sejarah sastra dan sejarah sastra di Indonesia melalui kegiatan terstruktur dan mandiri.

Tujuannya yaitu menghasilkan tulisan tentang temuan-temuan ciri khas berbagai periodisasi sejarah sastra Indonesia beserta problematika kehidupan sastranya yang akan dipresentasikan. Kurang optimalnya hasil belajar mahasiswa dipengaruhi oleh beberapa faktor, baik dari pemelajar dan pengajar. Sementara itu, perkuliahan harus dilaksanakan secara daring. Berdasarkan paparan tersebut, judul penelitian ini yaitu "Problematika pembelajaran daring mata kuliah Sejarah Sastra di Jurusan Bahasa dan Sastra Indonesia pada masa Pandemi Covid-19”. Tujuan penelitian adalah mendeskripsikan (1) problematika pembelajaran daring mata kuliah Sejarah Sastra di Jurusan Bahasa dan Sastra Indonesia pada masa Pandemi Covid-19, (2) solusi permasalahan pembelajaran daring mata kuliah Sejarah Sastra di Jurusan Bahasa dan Sastra Indonesia pada masa Pandemi Covid-19. Guna memperjelas konsep, akan disajikan kajian teoretis tentang problematika pembelajaran. Pemaparan mengenai bahan ajar mencakup faktor internal dan faktor eksternal. Sedangkan pada bagian pembelajaran dalam jaringan, akan dijelaskan mengenai ruang lingkup pengembangan bahan ajar pembelajaran daring.

\section{B. KAJIAN TEORI}

Menurut Dimyati dan Sudjiono problematika pembelajaran dibagi menjadi 2 yaitu faktor internal dan faktor eksternal. Faktor internal (1) sikap terhadap belajar, (2) motivasi belajar, (3) konsentrasi belajar, (4) kemampuan mengolah bahan belajar, (5) menggali hasil belajar yang tersimpan, (6) kemampuan berprestasi, (7) rasa percaya diri mahasiswa, (8) kebiasaan belajar dalam kegiatan sehari-hari. Sedangkan faktor eksternal terdiri dari (1) 


\section{Lingua Rima: Jurnal Pendidikan Bahasa dan Sastra Indonesia \\ Vol. 10 No. 1 Januari 2021 \\ http://jurnal.umt.ac.id/index.php//grm}

pengajar sebagai pembina mahasiswa dalam belajar, (2) sarana dan prasarana pembelajaran, (3) kebijakan penilaian.

Pembelajaran merupakan bentuk aktivitas yang terjadi di dalam kelas. Pembelajaran sebagai istilah esensinya juga mengacu pada model pengajaran. Rohani (2004:4) menjelaskan bahwa pengajaran merupakan dua aktivitas yang terintegrasi, yaitu aktivitas mengajar dan aktivitas belajar. Dipertegas pula oleh Thomas M. Risk (1958:5) bahwa mengajar merupakan proses membimbing pengalaman belajar. Pengalaman itu sendiri hanya mungkin diperoleh jika peserta didik itu dengan keaktifannya sendiri bereaksi terhadap lingkungannya. Guru dapat membantu peserta didik belajar tetapi guru tidak dapat belajar untuk anak itu. Jika seorang peserta didik ingin memecahkan suatu problem, ia harus berpikir menurut langkahlangkah tertentu. Lebih lanjut, dijelaskan pula prinsip-prinsip, pengajaran sebagai kunci keberhasilan pengajaran seperti di bawah ini. Prinsip-prinsip pengajaran sebagai kunci keberhasilan pengajaran harus dipahami oleh seorang pengajar. Prinsip-prinsip tersebut di antaranya: (a) prinsip aktivitas, (b) prinsip motivasi, (c) prinsip individualitas, (d) prinsip lingkungan, (e) prinsip konsentrasi, (f) prinsip kebebasan, (g) prinsip peragaan, (h) prinsip kerjasama dan persaingan, (i) prinsip apersepsi, (j) prinsip korelasi, (k) prinsip efisiensi dan efektivitas, (1) prinsip globalitas, dan (m) prinsip permainan dan hiburan (Rohani, 2004:6).

Di pihak lain, Zamroni (2000:32) menitikberatkan pada perlunya pembaharuan paradigma pernbelajaran di kelas. Pembaharuan tersebut menuntut kesiapan guru dan murid untuk menerima. Sesuai dengan kebutuhan murid, maka guru harus lebih aktif dalam merencanakan proses yang akan dilaksanakan, mempersiapkan bahan pelajaran, media pelajaran, metode pelajaran dan evaluasi serta tindak lanjut. Ruang lingkup dalam pengembangan bahan ajar pembelajaran daring Sejarah Sastra adalah (1) perencanaan pembelajaran daring, (2) perancangan materi pembelajaran daring, (3) penyampaian dan interaksi dalam pembelajaran daring, dan (4) evaluasi hasil belajar dan evaluasi program pembelajaran daring.

\section{METODE PENELITIAN}

Penelitian ini menggunakan pendekatan kualitatif deskriptif, merupakan metode pendekatan penelitian yang akan menghasilkan data deskriptif berupa data-data tertulis maupun lisan dari fenomena yang diamati langsung dan nyata tanpa ada kondisi yang diatur atau didesain dengan metode tertentu Bogdan (1992:3).

Sumber data penelitian didapatkan dari hasil angket mahasiswa semester 1 pembelajaran daring mata kuliah Sejarah Sastra. Lembar kerja mahasiswa mata kuliah Sejarah Sastra, dan rekam pembelajaran daring mata kuliah Sejarah Sastra.

Penelitian ini dilaksanakan di Jurusan Bahasa dan Sastra Indonesia. Waktu penelitian pada semester ganjil tahun ajaran 2020/2021. Subjek yang digunakan dalam penelitian ini ialah mahasiswa semester 1 pada program studi Pendidikan Bahasa dan Sastra Indonesia.

Teknik pengumpulan data yang digunakan dalam penelitian ini menggunakan teknik noninteraktif. Dalam teknik noninteraktif, sumber data berupa data atau benda yang tidak mengetahui bila sedang diamati atau dikaji. Teknik pengumpulan data dengan melakukan merekam data perkuliahan daring secara intensif dengan metode content analysis.

Teknik analisis data yang digunakan adalah metode analisis interaktif. Melibatkan beberapa komponen yaitu (1) Pengumpulan data dilakukan dengan menganalisis dokumentasi 
beruppa video/ foto rekam perkuliahan daring mata kulaih Sejarah Sastra, (2) reduksi data dengan menentukan data yang sesuai untuk penelitian, (3) penyajian data yang mengacu pada rumusan masalah yang telah ditentukan sebagai pertanyaan penelitian, dan (4) penarikan simpulan setelah melakukan reduksi dan sajian data lalu simpulan tersebut perlu diverifikasi supaya hasil penelitian dapat dipertanggungjawabkan.

\section{TEMUAN DAN PEMBAHASAN}

\section{Problematika pembelajaran daring mata kuliah Sejarah Sastra}

Selama masa pandemi Covid-19 pembelajaran daring menjadi pilihan yang tidak bisa ubah. Model pembelajaran berbasis internet dengan menggunakan beberapa aplikasi online yang membutuhkan sinyal internet stabil. Pembelajaran daring merupakan suatu pembelajaran yang dilakukan secara jarak jauh. Sehingga semua pembelajaran dilakukan secara daring di rumah masing-masing. Hal ini juga berlaku pada mata kuliah Sejarah Sastra yang dilaksanakan secara daring melalui Zoom ataupun Whatsapp. Metode pembelajaran ini menjadi solusi sementara yang dapat dilakukan agar proses belajar mengajar masih dapat berlangsung. Dosen masih tetap bisa mengajar dan mahasiswa tetap bisa belajar di rumah mereka selama pandemi ini. Pembelajaran daring sangat membutuhkan teknologi berbasis internet yang bergantung pada teknologi informasi.

Dalam hasil angket yang diberikan kepada mahasiswa menyatakan bahwa pembelajaran daring kurang efektif apabila dibandingkan dengan pembelajaran tatap muka secara langsung. Kesulitan utama yang dialami mahasiswa selama pembelajaran daring yakni kesulitan sinyal. Karena banyak dari mereka yang tinggal di rumah dengan kondisi sulit untuk mendapatkan akses internet yang baik. Sedangkan untuk mengikuti pembelajaran dengan menggunakan fitur Zoom membutuhkan koneksi internet yang kuat. Hal ini menyebabkan proses pembelajaran menjadi tidak maksimal. Mahasiswa menjadi kurang memahami materi yang disampaikan oleh dosen selama menerangkan materi.

Salah satu faktor internal yang menjadi problematika saat melakukan pembelajaran menurut Dimyati dan Sudjiono adalah konsentrasi belajar merupakan kemampuan memusatkan perhatian pada pelajaran dan kemampuan mengolah bahan belajar yakni kemampuan mahasiswa untuk menerima isi dan cara pemerolehan ajaran sehingga menjadi bermakna bagi mahasiswa. Hal ini berkaitan dengan permasalahan berikutnya yang dialami mahasiswa selama mengikuti pembelajaran secara daring. Mahasiswa menjadi kurang tertarik dan aktif selama masa perkuliahan.

\section{Solusi permasalahan pembelajaran daring mata kuliah Sejarah Sastra}

Berdasarkan problematika yang ditemukan selama perkuliahan daring selama ini, permasalahan utama yang menjadi substansi yaitu perkuliahan kurang interaktif sebab kendala dari masing-masing mahasiswa seperti buruknya sinyal, tidak adanya interaksi secara langsung, dan keterbatasan dalam memperdalam pemahaman mereka terhadap topik yang ada pada mata kuliah Sejarah Sastra. Oleh karena itu, bahan ajar perlu dibuat secara tepat yang tidak sekadar berisi latihan soal tetapi juga mengandung substansi materi. Semua itu dapat tergabung dalam lembar kerja mahasiswa (LKM).

Alasan logis LKM dijadikan sebagai solusi pada permasalahan daring karena dengan bahan ajar tersebut mampu mengakomodasi keaktifan mahasiswa selama pembelajaran jarak jauh. Mahasiswa perlu bahan untuk belajar secara mandiri sehingga sumber belajar mereka 


\section{Lingua Rima: Jurnal Pendidikan Bahasa dan Sastra Indonesia \\ Vol. 10 No. 1 Januari 2021 \\ http://jurnal.umt.ac.id/index.php/lgrm}

tidak hanya berasal dari dosen, tetapi juga berasal dari LKM tersebut. Selain itu, LKM mampu membantu pendidik dalam menyampaikan informasi (pengetahuan, sikap, dan kinerja) yang tidak bisa disampaikan secara lisan (Depdiknas, 2006; Rosidin, 2012).

Selama pembelajaran daring, LKM inilah yang berfungsi sebagai panduan mahasiswa dalam belajar dan menemukan konsep-konsep melalui aktivitass yang dilakukan. Pernyataan itu beriringan dengan pendapat Guruh, Anjarwati, dan Prayitno (2018) bahwa pemanfaatan LKM mampu membuat kegiatan belajar mahasiswa menjadi lebih terarah.

Mahasiswa yang menempuh mata kuliah Sejarah Sastra mendapatkan LKM dari dosen dan latihan soal dengan beberapa media yang dimanfaatkan seperti mengisi google form, kahoot, atau mengunggah hasil kerja mereka di google drive yang selanjutnya pranala diserahkan kepada dosen. Pemanfaatan LKM dan latihan soal yang beragam serta menarik akan memudahkan mahasiswa untuk belajar aktif sehingga mampu memberikan pengaruh positif terhadap daya berpikirnya (Sari dan Sugiyarto, 2015).

Saat pembelajaran daring berlangsung setiap media yang digunakan memiliki kekurangan dan kelebihannya masing-masing. Pada penggunaan google form terdapat beberapa kelebihan seperti layanan dapat diakses dengan gratis, tampilan yang diberikan tidak kompleks sehingga memudahkan pengguna. Selain itu, hasil dari google form terintegrasi dengan Google Sheets dan data yang didapatkan langsung ter-update secara otomatis. Lalu, hasil yang telah terolah dapat dibagian melalui surel atau pranala sehingga mampu dicetak secara luring dan diterima oleh responden (apabila dibutuhkan).

Kendala bagi pengajar yaitu desain yang ditawarkan dalam google form sangat terbatas dan data luaran yang diterima hanya dalam bentuk Google Sheets atau PDF saja. Selain itu, ketika ada responden yang mengisi form tidak akan masuk dalam pemberitahuan di surel. Perlu proses pengaktifan secara manual. Kekurangan lainnya yaitu tidak ada riwayat pengeditan. Hal itu menyebabkan tidak bisa dilihatnya perubahan-perubahan yang telah dikelola apabila form tersebut dipakai dalam tim.

Media kedua yang digunakan yaitu Kahoot. Pada media ini mahasiswa sangat tertarik karena bentuknya yang beragam dan penuh dengan warna. Suasana belajar jarak jauh tidak monoton dengan media yang sudah dipakai sebelumnya. Akan tetapi, Kahoot! memiliki kekurangan karena perlu sinyal yang kuat, apabila mahasiswa menggunakan ponsel perlu perangkat lain untuk melihat soal yang ditampilkan oleh guru agar bisa mengerjakannya. Hal itu sangat tidak efektif bagi mahasiswa yang minim dalam memiliki perangkat teknologi yang menunjang dengan baik.

Ketiga, pemanfaatan Google Drive dalam pembelajaran jarak jauh mata kuliah Sejarah Sastra. Google Drive memiliki keistimewaan karena memori yang dimiliki cukup besar serta mampu menyimpan file dalam berbagai format. File yang diunggah di sana dapat dibagikan dengan mudah dengan sistem keamanan yang cukup baik. Akan tetapi, mahasiswa merasa harus tergantung dengan jaringan internet untuk mengakses file. Selain itu, back-up data dari Google Drive hanya tersedia untuk data berbentuk foto dan video sedangkan untuk file jenis lainnya belum bisa.

Dari beberapa kendala yang dipaparkan, solusi yang diberikan yaitu adanya tambahan media agar mahasiswa menguasai secara utuh mata kuliah Sejarah Sastra. Peneliti memberikan solusi adanya lembar kerja mahasiswa (LKM). Materi yang ada di LKM sudah 
divalidasi oleh dua dosen yang ahli dalam materi. Selain berisi ringkasan materi juga terdapat beberapa latihan soal yang bertujuan mengasah pengetahuan mahasiswa terhadap setiap materi yang telah dipaparkan.

\section{Hasil Validasi Lembar Kerja Mahasiswa}

Hasil validasi LKM dilakukan oleh dua orang dosen Fakultas Bahasa dan Seni Universitas Negeri Surabaya. Penilaian diberikan validator dengan memberi tanda check $(\sqrt{ })$ pada daftar indikator yang tertera dan diolah rating-nya oleh peneliti. Kriteria validasi instumen yaitu struktur LKM, organisasi penulisan LKM, dan bahasa. Berikut hasil validasi LKM yang telah dilakukan dapat dilihat pada tabel ini.

Tabel 1. Skor Validitas LKM

\begin{tabular}{|l|l|l|}
\hline Validitas & Rata-Rata Penilaian & Kategori \\
\hline Validitas Struktur & 4,3 & Valid \\
\hline $\begin{array}{l}\text { Validitas Organisasi } \\
\text { Penulisan }\end{array}$ & 4,3 & Valid \\
\hline Validitas Bahasa & 5 & Sangat Valid \\
\hline
\end{tabular}

Berdasarkan data tabel tersebut rata-rata penilaian LKM pada aspek validitas struktur 4,3 telah memenuhi kategori valid dan 4,5 pada aspek validitas organisasi penulisan yang memenuhi kategori valid. Selain itu, aspek validitas bahasa masuk kategori sangat valid karena rata-rata penilaiannya yaitu 5 .

\section{E. SIMPULAN}

Hasil angket problematika pembelajaran daring mata kuliah Sejarah Sastra terletak pada proses evaluasi pembelajaran yang belum bisa diwadahi dengan sesi diskusi/tanya jawab. Solusi yang diwarkan pada penelitian ini adalah penggunaan Lembar Kerja Mahasiswa (LKM) dalam bentuk daring yang disampaikan menggunakan google drive, google form, dan kahoot. Selain latihan soal yang dapat dijadikan sebagai bahan memperdalam materi, LKM juga dilengkapi dengan ringkasan materi pada setiap topik pertemuan.

\section{F. DAFTAR PUSTAKA}

Bogdan, R. dan Taylor, S. 1992. Pengantar Metode Kualitatif. Surabaya: Usaha Nasional.

Risk, T. M. 1958. Principles and Practices of Teaching. New York.

Rohani, A. 2004. Pengelolaan Pengajaran. Jakarta. PT. Rineka Cipta

Sari, D.S., \& Sugiyarto, K.H. (2015). Pengembangan Multimedia Berbasis Masalah untuk Meningkatkan Motivasi Belajar dan Kemampuan Berpikir Kritis Siswa. Jurnal Inovasi Pendidikan IPA, $1(2)$, $153-166$. http://journal.uny.ac.id/index.php/jipi\%5CnPENGEMBANGAN Zamroni. 2000. Paradigma Pendidikan Masa Depan. Yogyakarta: Bigraf Publishing 